\title{
Jurnal Dinamis
}

Vol. 9, No. 2, Bulan Tahun | 12-21

ISSN : 0216-7492, e-ISSN : 2809-3410

Homepage : https://talenta.usu.ac.id/dinamis

\section{KAJIAN TEORITIS PENGGUNAAN TURBOCHARGER TERHADAP PERFORMANSI MESIN BENSIN TIPE 3SZ-VE 1500 CC DAIHATSU TERIOS}

\author{
Dian Morfi Nasution ${ }^{1 *}$, Amirsyam Nasution ${ }^{2}$, Surya Darma Ginting ${ }^{3}$ \\ ${ }^{1}$ Departemen Teknik Mesin, Fakultas Teknik, Universitas Sumatera Utara, Medan, 20155, Indonesia \\ ${ }^{2}$ Program Studi Teknik Mesin, Fakultas Teknik, Universitas Medan Area, Medan, 20233, Indonesia \\ ${ }^{3}$ Program Studi Teknik Mesin, Fakultas Teknik, Universitas Harapan, Medan, 20228, Indonesia \\ *E-mail: dianmorfinasution@usu.ac.id
}

\begin{abstract}
Abstrak
Kunci keuntungan dari turbocharger adalah alat ini menawarkan sebuah peningkatan yang cukup banyak dalam tenaga mesin hanya dengan sedikit menambah berat. Tujuan kajian teoritis ini adalah untuk mendapatkan parameter termodinamika mesin bensin tanpa dan dengan penggunaan turbocharger, mendapatkan performansi mesin bensin tanpa dan dengan penggunaan turbocharger, dan mendapatkan daya dan putaran turbin gas dan kompresor pada turbocharger. Dalam kajian teoritis ini menggunakan data spesifikasi teknis mesin mobil tipe 3SZ-VE. Hasil analisa termodinamika daya bersih $\mathrm{W}_{\text {nett }}$ dengan penggunaan turbocharger meningkat sebanyak 20,29\% dibandingkan tanpa penggunaan turbocharger. Performansi mesin tanpa turbocharger diperoleh mep sebesar $2691,906 \mathrm{kPa}$, $\mathrm{P}_{\mathrm{i}}$ pada putaran $4400 \mathrm{rpm}$ sebesar 147,5613 kW, $\mathrm{P}_{\mathrm{s}}$ sebesar $65,09 \mathrm{~kW}$, sfc sebesar 292,675 gram/kW. jam, $\eta_{\mathrm{m}}$ sebesar 44,11\%, dan $\eta_{\mathrm{v}}$ sebesar 98,46\%. Performansi dengan turbocharger diperoleh mep sebesar 3238,314 kPa, $\mathrm{P}_{\mathrm{i}}$ pada putaran $4400 \mathrm{rpm}$ sebesar 177,5136 kW, $\mathrm{P}_{\mathrm{s}}$ sebesar 65,09 kW, sfc sebesar 355,379 gram/kW.jam, $\eta_{\mathrm{m}}$ sebesar $36,66 \%$ dan $\eta_{\mathrm{v}}$ sebesar $98,45 \%$. Daya turbocharger sebesar $3,54915 \mathrm{~kW}$ dengan putaran $59200 \mathrm{rpm}$ pada saat putaran mesin bensin $6000 \mathrm{rpm}$.
\end{abstract}

Kata kunci: turbocharger, performansi, mesin bensin

\begin{abstract}
The key advantage of a turbocharger is that it offers a considerable increase in engine power with just a little added weight. The purpose of this theoretical study is to obtain thermodynamic parameters of motor gasoline without and with the use of a turbocharger, get gasoline motor fuel performance without and with the use of a turbocharger, and get the power and gas turbine wheel and compressor on the turbocharger. In this theoretical study, data on the technical specifications of the 3SZ-VE type car engine are used. Thermodynamic analysis results with the use of turbocharger for net power increased by 20.29\% compared to without the use of a turbocharger. The performance of the engine without a turbocharger obtained mep at $2691.906 \mathrm{kPa}, \mathrm{P}_{\mathrm{i}}$ for $4400 \mathrm{rpm}$ is 147.5613 $\mathrm{kW}$, of $65.09 \mathrm{~kW}$, sfc amounted to $292.675 \mathrm{gram} / \mathrm{kWh}$, amounted to $44.11 \%$, and by $98,46 \%$. The performance of the turbocharger obtained mep at $3238.314 \mathrm{kPa}, \mathrm{P}_{\mathrm{i}}$ for $4400 \mathrm{rpm}$ is $177.5136 \mathrm{~kW}$, of $65.09 \mathrm{~kW}$, sfc amounted to $355.379 \mathrm{gram} / \mathrm{kWh}$, amounted to $36.66 \%$ and amounted to $98.45 \%$. Turbocharger power of $3.54915 \mathrm{~kW}$ at 59200 rpm when the gasoline engine revolution of $6000 \mathrm{rpm}$.
\end{abstract}

Keywords: turbocharger, performance, gasoline engine

\section{PENDAHULUAN}

Turbocharger ditemukan oleh seorang Insinyur Swiss, Alfred Buchi. Patennya untuk turbocharger diaplikasikan untuk dipakai tahun 1905. Lokomotif dan kapal bermesin diesel dengan turbocharger mulai terlihat tahun 1920-an. Komponen mesin ini memiliki tiga bagian penting yaitu roda turbin, roda kompressor dan rumah as. Roda turbin yang bersudu-sudu ini berputar memanfaatkan tekanan gas buang keluar, kemudian melalui as terputarnya roda turbin ini berputar pula roda kompressor dengan sudu-sudunya sehingga memompa udara masuk dalam massa yang padat [1]. Pengembangan otomotif bertujuan membuat mobil ramah terhadap lingkungan sekaligus tetap baik dikendarai. Kendati yang didapat dari suatu komponen kecil, namun dengan jumlahnya yang banyak, hasilnya akan menjadi besar. Karena itulah berbagai pengembangan dilakukan terhadap komponen mesin. Untuk membuat ukuran mesin makin kecil namun tetap menghasilkan tenaga dan torsi besar, pencangkokkan turbocharger pada mesin bensin makin mewabah. Utamanya dilakukan oleh produsen dari Jerman yang umumnya memproduksi mobil premium atau mewah. BMW membanggakan twin-turbo, Mercedes-Benz dengan CGI. Bahkan produsen yang disebut terakhir berani mengganti teknologi kompresor yang dulu dibanggakannya dengan turbocharger. Hal yang sama juga dilakukan oleh Audi dan VW. Tahun depan makin banyak mobil Eropa yang 
menggunakan platform turbo. Teknologi tersebut diberi nama antara lain, Efficient Dynamics (BMW), Blue Efficiency (MB) dan Blue Motion (VW).

Semakin tertariknya produsen mobil mewah menggunakan turbocharger karena pengontrol kerjanya makin canggih dan turbocharger sudah bekerja pada putaran rendah. Aliran gas buang yang mengaktifkan turbo kini diatur oleh katup yang bekerja secara elektrik [2]. Ibrahim Santoso (2006), melakukan perancangan turbin gas dan blower pada turbocharger untuk motor bensin sekelas sedan 1500 cc. Hasil perhitungan diperoleh peningkatan daya efektif mesin mencapai $42 \%$ dan mengurangi konsumsi bahan bakar spesifik $6 \%$ [3]. Agustinus Made (2011), merancang kompresor sentrifugal pada turbocharger motor bensin 1500 cc untuk menaikkan daya maksimal mesin sebesar 25\%. Hasil yang diperoleh tekanan udara dapat ditingkatkan sebesar 0,382 atm dengan putaran turbocharger 50000 rpm [4].

Tujuan penelitian ini adalah (1) mendapatkan parameter termodinamika mesin bensin tanpa dan dengan penggunaan turbocharger yaitu kalor yang disuplai ke dalam silinder mesin, kerja yang dihasilkan, kalor yang dibuang, dan efisiensi termal siklus; (2) mendapatkan performansi mesin bensin tanpa dan dengan penggunaan turbocharger yaitu tekanan efektif rata-rata, daya indikator, daya poros, konsumsi bahan bakar spesifik, efisiensi termal, efisiensi mekanis, efisiensi volumetrik, serta perbandingan performansi; dan (3) mendapatkan daya dan putaran turbin gas dan kompresor pada turbocharger.

\section{METODE PENELITIAN}

Mesin bensin atau motor bensin dikenal dengan mesin Otto yang bekerja dengan gerakan torak bolak balik (bergerak naik turun pada motor tegak) dengan prinsip 4 langkah dan 2 langkah (Gambar 1).

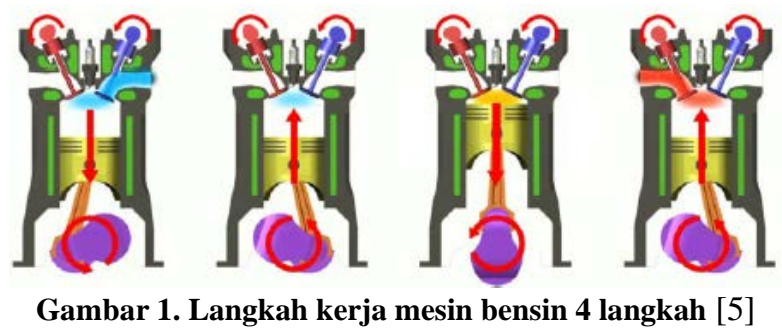

Siklus Otto dikemukakan oleh Nikolaus A. Otto setelah berhasil membangun sebuah mesin empat langkah pada tahun 1876 di Jerman menggunakan siklus yang diajukan oleh Frenchman Beau de Rochas pada tahun 1862 [6]. Siklus Otto adalah siklus ideal untuk mesin torak dengan pengapian nyala bunga api. Pada mesin pembakaran dengan sistem pengapian-nyala ini, campuran bahan bakar dan udara dibakar dengan menggunakan percikan bunga api dari busi. Piston bergerak dalam empat langkah (disebut juga mesin dua siklus) dalam silinder, sedangkan poros engkol berputar dua kali untuk setiap siklus termodinamika. Mesin seperti ini disebut mesin pembakaran internal empat langkah. Siklus Otto aktual diperlihatkan pada Gambar 2. Fluida kerjanya adalah campuran bahan bakar - udara, jadi ada proses pembakaran untuk sumber panas. Pada langkah hisap, tekanannya lebih rendah dibandingkan dengan langkah buang. Proses pembakaran dimulai dari penyalaan busi (ignition) sampai akhir pembakaran. Proses kompresi dan ekspasi tidak adiabatis, karena terdapat kerugian panas yang keluar ruang bakar.

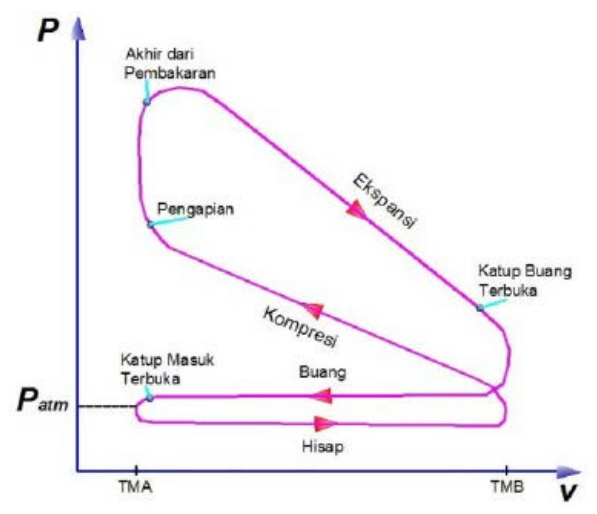

Gambar 2. Diagram $p-v$ Siklus Otto aktual [6] 


\section{Turbocharger}

Pada prinsipnya supercharger dan turbocharger mempunyai tujuan yang sama, yaitu memperbesar jumlah udara yang masuk ke dalam silinder. Hal ini bertujuan meningkatkan daya motor tanpa memperbesar kapasitas motor tersebut. Ada perbedaan dalam proses kerja antara supercharger dan turbocharger, yaitu pada penggerak impeler turbin dimana pada supercharger impeler turbin digerakkan oleh gerakan mekanik yang ditransfer dari putaran poros engkol, sedangkan pada turbocharger memanfaatkan gas buang sebagai penggerak impeler turbin. Skema instalasi turbocharger sederhana terlihat pada Gambar 3. Sebuah mesin bensin empat langkah yang bekerja dengan turbocharger tekanan isapnya lebih tinggi dari tekanan atmosfer sekitarnya. Hal ini diperoleh dengan jalan memaksa udara atmosfer masuk kedalam silinder selama langkah isap. Dengan cara mendinginkan udara bertekanan sebelum masuk kedalam silinder turbocharger dengan intercooler diharapkan bisa memperoleh tekanan efektif rata-rata yang lebih besar dengan mengurangi turunnya kerapatan udara akibat temperatur yang tinggi. Sehingga akan dihasilkan daya yang lebih besar denga ukuran mesin yang sama.

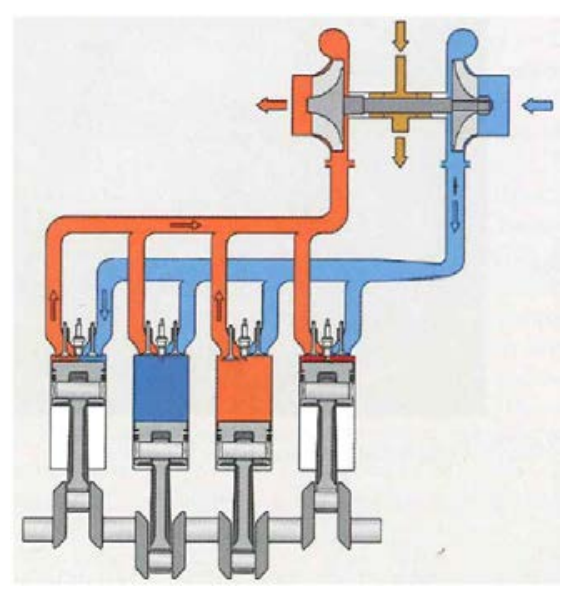

Gambar 3. Skema sederhana turbocharger [7]

Tujuan utama penggunaan turbocharger adalah untuk memperbesar daya motor, turbo sudah bekerja pada putaran rendah. Boleh dikatakan bahwa mesin dengan turbocharger dapat bekerja lebih effisien, apabila mesin harus bekerja pada ketinggian lebih dari 1500 meter diatas permukaan laut, turbocharger mempunyai arti penting dalam usaha mengatasi kerugian daya yang disebabkan oleh berkurangnya kepadatan udara atmosfer di tempat tersebut [8].

\section{Siklus Otto dengan Turbocharger}

Siklus Otto udara standar dengan penggunaan turbocharger diperlihatkan dengan diagram $p-V$ pada Gambar 4.

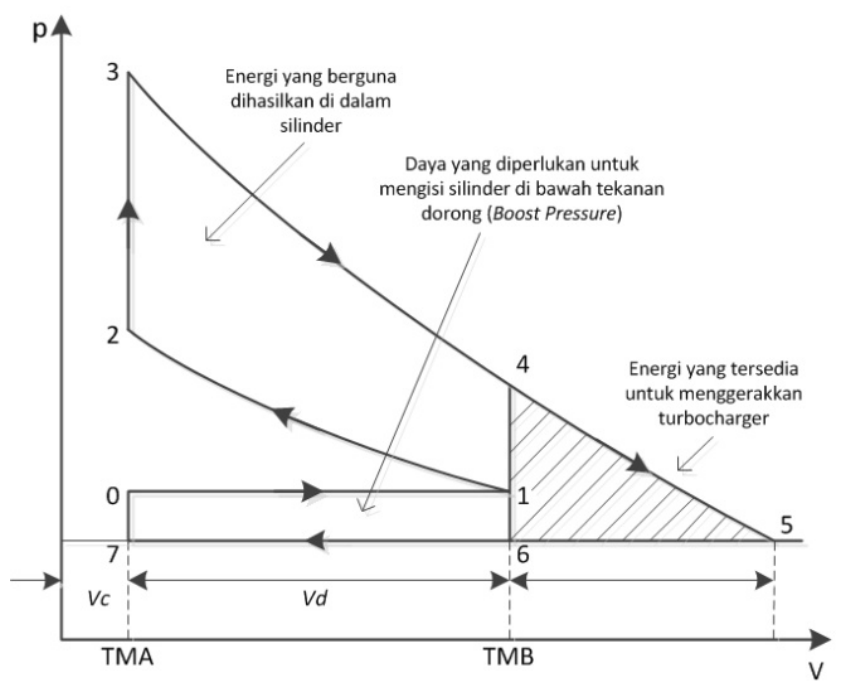

Gambar 4. Diagram $p-V$ siklus Otto ideal menggunakan turbocharger [9] 
Energi ideal yang dapat digunakan untuk menggerakkan turbocharger berasal dari energi gas buang yang digambarkan dalam area 4-5-6 pada Gambar 2.20 dan selanjutnya diekspansi hingga tekanan atmosfir $\left(p_{6}=p_{a t m}\right)$. Area 6-7-0-1 menggambarkan jumlah energi yang dibutuhkan untuk mengisi silinder. Dengan kata lain bahwa area 4-5-6 merupakan tugas turbin untuk menggerakkan kompresor dan area 6-7-0-1 merupakan tugas kompresor untuk meyediakan kebutuhan silinder. Area 1-2-3-4 proses siklusnya sama dengan siklus Otto udara standar. Langkah untuk menganalisa penggunaan turbocharger antara lain:

1. Mengacu literatur [7] temperatur gas buang yang masuk ke turbin turbocharger untuk aplikasi mesin bensin berkisar antara $550-855^{\circ} \mathrm{C}$, sedangkan pada literatur [10] menyebutkan temperatur gas buang maksimum masuk turbin mencapai $1050^{\circ} \mathrm{C}(1323 \mathrm{~K})$ untuk mesin modern. Literatur [13] menyajikan temperatur gas masuk turbin diantara $500 \mathrm{~K}$ sampai $1300 \mathrm{~K}$ dengan tekanan masuk antara $120 \mathrm{kPa}$ sampai $300 \mathrm{kPa}$.

2. Tekanan gas keluar turbin sama dengan tekanan udara atmosfir.

3. Tekanan dan temperatur udara masuk kompresor adalah standar atmosfir.

4. Tekanan udara yang disuplai kompresor ke dalam silinder (tekanan udara keluar kompresor) mengacu pada literatur [11] untuk penggunaan turbocharger tanpa pendinginan udara yaitu berkisar antara 1,2 sampai 1,5 atm. Setelah ditetapkan parameter untuk kondisi turbocharger selanjutnya dilakukan analisa termodinamika pada turbin dan kompresor turbocharger sebagai berikut:

a) Analisa Termodinamika pada Turbin Turbocharger

Proses termodinamika yang berlangsung pada turbin ditunjukkan dengan diagram T-s pada Gambar 5, dimana proses adiabatis ideal berubah menjadi kondisi stagnasi.

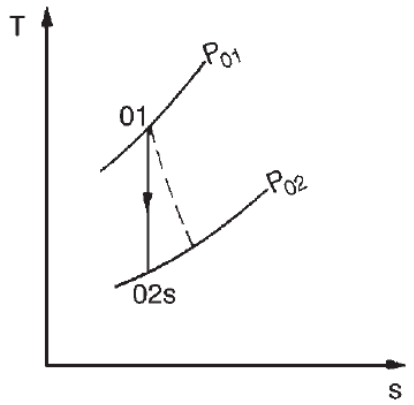

Gambar 5. Diagram T-s untuk turbin [12]

Temperatur gas keluar turbin pada kondisi isentropik $T_{02 s}$ dapat diperoleh dengan Persamaan (1) berikut

$$
\frac{T_{02 s}}{T_{01}}=\left(\frac{p_{02}}{p_{01}}\right)^{\frac{k-1}{k}}
$$

Temperatur gas keluar turbin pada kondisi stagnasi $T_{02}$ dapat diperoleh dengan Persamaan (2) berikut

$$
\eta_{T}=\frac{T_{01}-T_{02}}{T_{01}-T_{02 s}}
$$

b) Analisa Termodinamika pada Kompresor Turbocharger

Proses termodinamika yang berlangsung pada kompresor ditunjukkan dengan diagram $T$-s pada Gambar 6 dimana keadaan udara masuk stagnasi ditunjukkan pada titik 01, sedangkan keadaan udara keluar kompresor kondisi stagnasi pada titik 02, dan titik 02s menunjukkan kondisi pada keadaan isentropik.

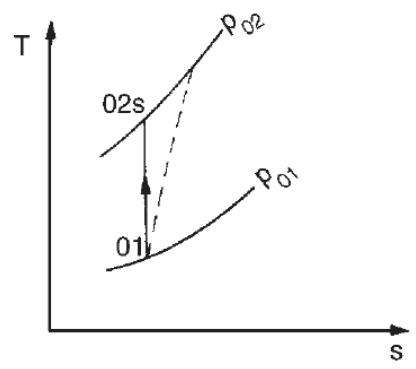

Gambar 6. Diagram T-s kompresor [12] 
Temperatur udara keluar kompresor pada kondisi isentropik $T_{02 s}$ dapat diperoleh dengan Persamaan (3) berikut

$$
\frac{T_{02 s}}{T_{01}}=\left(\frac{p_{02}}{p_{01}}\right)^{\frac{k-1}{k}}
$$

Temperatur udara keluar kompresor pada kondisi stagnasi $T_{02}$ dapat diperoleh dengan Persamaan (4) berikut

$$
\eta_{c}=\frac{T_{02 s}-T_{01}}{T_{02}-T_{01}}
$$

Turbin digerakkan oleh gas buang dari mesin yang mengkopel langsung kompresor, sehingga daya yang diperlukan untuk memutar kompresor adalah daya yang dihasilkan turbin.

$$
\begin{gathered}
W_{\text {Turbin }}=W_{\text {Kompresor }} \\
\dot{m}_{e x}\left(h_{01}-h_{02}\right)=\dot{m}_{u, c}\left(h_{02}-h_{01}\right)
\end{gathered}
$$

$h_{01}$ merupakan harga entalpi pada $T_{01}$ dan $h_{02}$ merupakan harga entalpi pada $T_{02}$ pada masing-masing turbin dan kompresor. Laju aliran udara melalui kompresor dengan Persamaan (7)

$$
\dot{m}_{u}=\frac{\eta_{v} \times \rho_{u} \times V_{d} \times N \times z}{n}
$$

Untuk $z$ adalah jumlah silinder mesin. Putaran turbocharger ditentukan dengan grafik karakteristik kompresor Gambar 7 berikut ini.

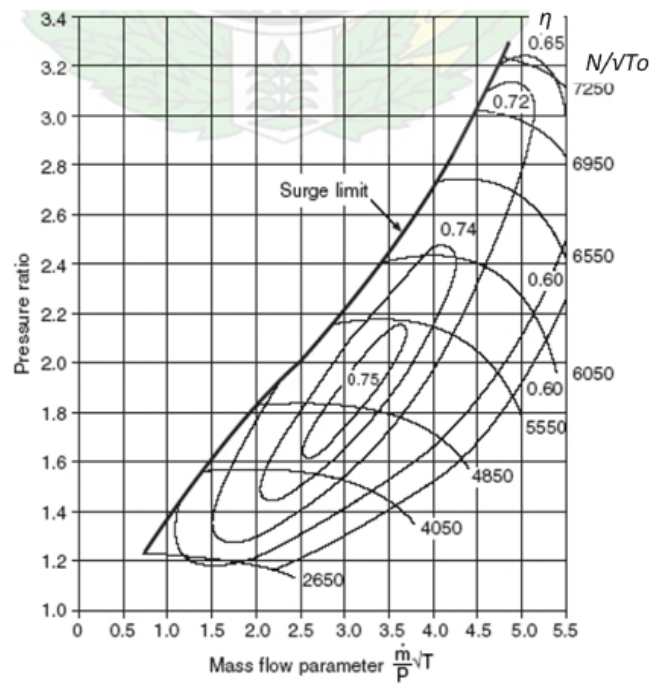

Gambar 7. Grafik karakteristik kompresor sentrifugal

\section{Parameter Performansi Mesin Bensin}

a) Tekanan efektif rata-rata (

Selama siklus berlangsung, temperatur dan tekanannya selalu berubah-ubah. Oleh karena itu sebaiknya dicari harga tekanan tertentu (konstan) yang apabila mendorong torak sepanjang langkahnya dapat menghasilkan kerja persiklus yang sama dengan siklus yang dianalisis. Tekanan tersebut dinamai tekanan efektif rata-rata (mep) yang diperoleh menggunakan Persamaan (8) [6].

$$
m e p=\frac{W_{\text {nett }}}{V_{d}}
$$

mep merupakan tekanan efektif rata-rata $(\mathrm{kPa})$. 
b) Daya Indikator $\left(P_{i}\right)$

Merupakan daya yang dihasilkan dalam silinder mesin sehingga merupakan basis perhitungan atau penentuan efisiensi pembakaran atau besarnya laju panas akibat pembakaran di dalam silinder dengan bentuk Persamaan (9).

$$
P_{i}=\frac{W_{n e t t} \times N}{n}
$$

$P_{i}$ adalah daya indikator $(\mathrm{kW}), N$ sebagai putaran mesin (revolution per minutes/rpm), dan $n$ jumlah putaran dalam satu siklus, untuk 4 tak nilai $n$ adalah 2 (putaran/siklus).

c) Daya Poros $\left(P_{s}\right)$

Daya yang dihasilkan suatu mesin pada poros keluarannya disebut sebagai daya poros (atau biasa dikenal dengan brake horse power) yang dihitung berdasarkan Persamaan (10).

$$
P_{S}=\frac{2 \pi \times N \times T}{60 \times 1000}
$$

$P_{s}$ daya poros $(\mathrm{kW})$ dan $T$ torsi yang dihasilkan (Nm). Seperti yang telah diketahui, dari sejumlah gaya yang dihasilkan mesin, maka sebagian darinya dipakai untuk mengatasi gesekan/friksi antara bagian-bagian mesin yang bergerak, sebagian lagi dipakai untuk mengisap udara dan bahan bakar serta mengeluarkannya dalam bentuk gas buang.

d) Konsumsi bahan bakar spesifik ( $s f c)$

Konsumsi bahan bakar didefenisikan sebagai jumlah bahan bakar yang dikonsumsi persatuan unit daya yang dihasilkan perjam operasi. Secara tidak langsung konsumsi bahan bakar spesifik merupakan indikasi efisiensi mesin dalam menghasilkan daya dari pembakaran bahan bakar yang dihitung dengan Persamaan (11).

$$
s f c=\frac{\dot{m_{f}}}{P_{s}}
$$

sfc konsumsi bahan bakar spesifik (gr/kWh) danm $\dot{f}_{f}$ laju aliran massa bahan bakar (kg/s).

\section{e) Efisiensi Termal}

Efisiensi termal suatu mesin didefenisikan sebagai perbandingan antara energi keluaran dengan energi kimia yang masuk yang dikandung bahan bakar dalam bentuk bahan bakar yang dihisap ke dalam ruang bakar. Efisiensi termal merupakan parameter untuk mengukur efisiensi bahan bakar yang diberikan dengan Persamaan (12).

$$
\eta_{t h}=\frac{P_{i}}{m_{f} \times L H V_{B B}} \times 100 \%
$$

$\eta_{t h}$ efisiensi termal (\%) dan $L H V_{B B}$ low heating value atau nilai kalor bawah bahan bakar (kJ/kg).

f) Efisiensi Mekanis

Besarnya kerugian daya diperhitungkan dalam efisiensi mekanis yang dirumuskan pada Persamaan (13).

$$
\eta_{m}=\frac{P_{s}}{P_{i}} \times 100 \%
$$

$\eta_{m}$ efisiensi mekanis (\%).

g) Efisiensi Volumetrik

Efisiensi ini didefenisikan sebagai perbandingan antara massa udara yang masuk karena dihisap torak pada langkah hisap dan massa udara pada tekanan dan temperatur atmosfir yang dapat dihisap masuk ke dalam volume langkah torak yang sama dengan bentuk Persamaan (14).

$$
\eta_{v}=\frac{m_{u}}{\rho_{u} \times v_{d}} \times 100 \%
$$


$\eta_{v}$ efisiensi volumetrik (\%), $m_{u}$ massa udara yang masuk (kg), dan $\rho_{u}$ kerapatan udara yang masuk $\left(\mathrm{kg} / \mathrm{m}^{3}\right)$.

Dalam kajian teoritis ini menggunakan data spesifikasi teknis mesin mobil Daihatsu Terios dengan spesifikasi pada Tabel 1. Model turbocharger yang cocok untuk diaplikasikan pada mesin Daihatsu Terios yaitu Turbocharger Toyota Model CT-9 yang merupakan model turbocharger toyota yang familiar untuk mesin bensin, turbo ini pernah dipakai pada mesin toyota Starlet dengan kapasitas 1300 cc dan daya 133HP. CT-9 ini memiliki diameter roda kompresor inlet $34 \mathrm{~mm}$ dan outlet $48 \mathrm{~mm}$ serta diameter turbin $46 \mathrm{~mm}$. Model turbocharger ini diperlihatkan pada Gambar 8 [14].

Tabel 1. Spesifikasi mesin Daihatsu Terios

\begin{tabular}{|l|l|}
\hline Tipe mesin & 3SZ-VE DOHC VVT-i, berpendingin air, 4 langkah \\
\hline Kapasitas silinder & $1495 \mathrm{cc}\left(\mathrm{cm}^{3}\right)$ \\
\hline Jumlah silinder & 4 buah segaris \\
\hline Jumlah katup & 16 buah \\
\hline Diameter x langkah & $72,0 \mathrm{~mm}$ x 91,8 mm \\
\hline Tenaga maksimum & 109 PS @ 6000 rpm atau $80.169 \mathrm{~kW} @ 6000 \mathrm{rpm}$ \\
\hline Torsi maksimum & 14,4 kgf.m @ 4400 rpm \\
\hline Sistem bahan bakar & Electronic Fuel Injection (EFI) \\
\hline Bahan bakar & Bensin tanpa timbal \\
\hline Rasio kompresi & $10: 1$ \\
\hline Rasio udara bahan bakar & $12: 1$ \\
\hline Kapasitas tangki bahan bakar & 45 Liter \\
\hline
\end{tabular}

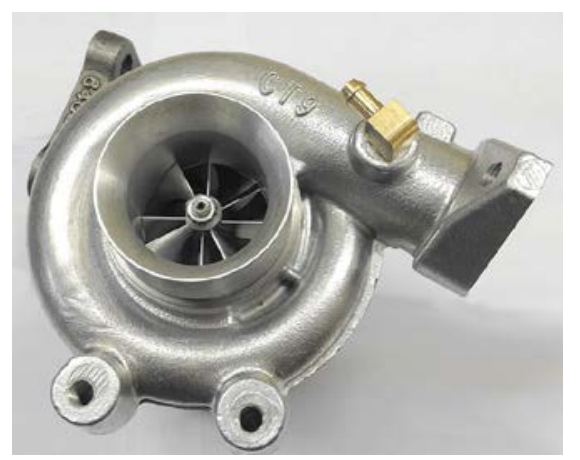

Gambar 8. Turbocharger Toyota model CT9

\section{HASIL DAN PEMBAHASAN}

\section{Analisa Termodinamika}

Analisa termodinamika pada siklus Otto udara standar yang diperlihatkan dengan diagram $p-V$ pada Gambar 9. 


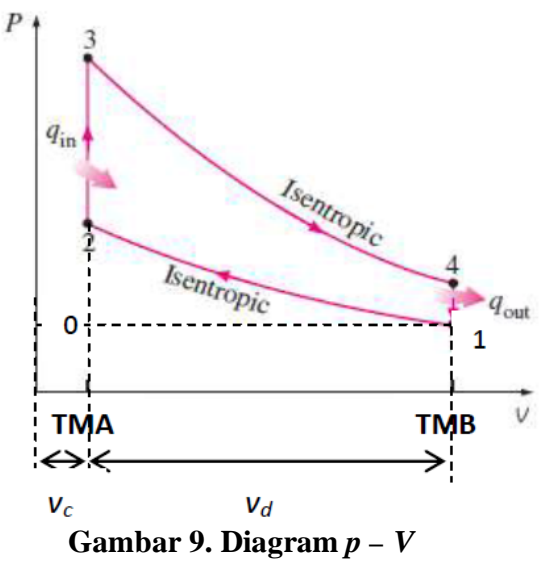

Dari hasil analisa diperoleh nilai-nilai untuk kondisi titik 1,2,3, dan 4 yang diberikan pada Tabel 2.

Tabel 2. Parameter untuk kondisi tiap titik siklus Otto udara standar

\begin{tabular}{|c|c|}
\hline Kondisi titik 1 & Kondisi titik 2 \\
\hline $\mathrm{p}_{1}=101,325 \mathrm{kPa}$ & $\mathrm{p}_{2}=2545,1689 \mathrm{kPa}$ \\
\hline $\mathrm{T}_{1}=300 \mathrm{~K}\left(27^{\circ} \mathrm{C}\right)$ & $\mathrm{T}_{2}=753,5659 \mathrm{~K}$ \\
\hline $\mathrm{V}_{1}=0,00041527 \mathrm{~m}^{3}$ & $\mathrm{~V}_{2}=0,000041527 \mathrm{~m}^{3}$ \\
\hline Kondisi titik 3 & Kondisi titik 4 \\
\hline $\mathrm{p}_{3}=18514,067 \mathrm{kPa}$ & $\mathrm{p}_{4}=737,058 \mathrm{kPa}$ \\
\hline $\mathrm{T}_{3}=5481,589 \mathrm{~K}$ & $\mathrm{~T}_{4}=2182,259 \mathrm{~K}$ \\
\hline $\mathrm{V}_{3}=0,000041527 \mathrm{~m}^{3}$ & $\mathrm{~V}_{4}=0,00041527 \mathrm{~m}^{3}$ \\
\hline
\end{tabular}

Parameter nilai yang ditetapkan untuk menganalisa penggunaan turbocharger antara lain:

1. Mengacu literatur [7] temperatur gas buang yang masuk ke turbin turbocharger untuk aplikasi mesin bensin berkisar antara 550-855 ${ }^{\circ} \mathrm{C}$, sedangkan pada literatur [10] menyebutkan temperatur gas buang maksimum masuk turbin mencapai $1050^{\circ} \mathrm{C}(1323 \mathrm{~K})$ untuk mesin modern. Literatur [13] menyajikan temperatur gas masuk turbin diantara $500 \mathrm{~K}$ sampai $1300 \mathrm{~K}$ dengan tekanan sampai $300 \mathrm{kPa}$. Dalam kajian ini diambil nilai temperatur gas buang masuk turbin $T_{T, \text { in }}=1300 \mathrm{~K}\left(1027^{\circ} \mathrm{C}\right)$ dengan melihat nilai temperatur $T_{4}$. Gas buang diasumsikan mengalami ekspansi pada saluran pipa menuju roda turbin turbocharger.

2. Tekanan gas buang masuk turbin diperoleh dengan hubungan berikut:

$$
\begin{aligned}
& \frac{T_{T, \text { in }}}{T_{4}}=\left(\frac{p_{T, i n}}{p_{4}}\right)^{\frac{k-1}{k}} \\
& p_{T, \text { in }}=p_{5}=\left(\sqrt{\frac{k-1}{k}} \sqrt{\frac{T_{T, i n}}{T_{4}}}\right) p_{4}=\left(\sqrt[\frac{1,4-1}{1,4}]{\frac{1300}{2182,259}}\right) \times 737,058=120,262 \mathrm{kPa}
\end{aligned}
$$

3. Tekanan gas keluar turbin sama dengan tekanan udara atmosfir yaitu $p_{T, \text { out }}=p_{6}=101,325 \mathrm{kPa}$.

4. Tekanan dan temperatur udara masuk kompresor yaitu $p_{c, \text { in }}=p_{0}=101,325 \mathrm{kPa}$ dan $T_{c, \text { in }}=T_{0}=$ $300 K\left(27^{\circ} \mathrm{C}\right)$.

5. Tekanan udara yang disuplai kompresor ke dalam silinder (tekanan udara keluar kompresor) mengacu pada literatur [20] untuk penggunaan turbocharger tanpa pendinginan udara yaitu berkisar antara 1,2 sampai 1,5 atm. Dalam kajian ini diambil tekanan udara yang disuplai $p_{c, \text { out }}=p_{1}=1,35 \mathrm{~atm}=136.788 \mathrm{kPa}$.

Hasil analisa termodinamika pada kondisi kerja turbin dan kompresor turbocharger dapat dilihat pada Tabel 3.

Tabel 3. Hasil analisa termodinamika turbocharger

\begin{tabular}{|l|}
\hline \multicolumn{1}{|c|}{ Turbin } \\
\hline Tekanan gas masuk turbin \\
$p_{T, \text { in }}=p_{01}=120,262 \mathrm{kPa}$ \\
\hline
\end{tabular}




\begin{tabular}{|l|}
\hline Temperatur gas masuk turbin \\
$T_{T, \text { in }}=T_{01}=1300 \mathrm{~K}$ \\
\hline Entalpi gas masuk turbin \\
$h_{01}=1395,97 \mathrm{~kJ} / \mathrm{kg}$ \\
\hline Tekanan gas keluar turbin \\
$p_{T, \text { out }}=p_{02}=101,325 \mathrm{kPa}$ \\
\hline Temperatur gas keluar turbin \\
$T_{T, \text { out }}=T_{02}=1250,312 \mathrm{~K}$ \\
\hline Entalpi gas keluar turbin \\
$h_{02}=1337,108 \mathrm{~kJ} / \mathrm{kg}$. \\
\hline \multicolumn{1}{|c|}{ Kompresor } \\
\hline Tekanan udara masuk kompresor \\
$p_{c, \text { in }}=p_{01}=101,325 \mathrm{kPa}$ \\
\hline Temperatur udara masuk kompresor \\
$T_{c, \text { in }}=T_{01}=300 \mathrm{~K}$ \\
\hline Entalpi udara masuk kompresor \\
$h_{01}=300,19 \mathrm{~kJ} / \mathrm{kg}$ \\
\hline Tekanan udara keluar kompresor (suplai) \\
$p_{c, \text { out }}=p_{02}=136,788 \mathrm{kPa}$ \\
\hline Temperatur udara keluar kompresor (suplai) \\
$T_{c, \text { out }}=T_{02}=333,57 \mathrm{~K}$ \\
\hline Entalpi udara keluar kompresor \\
$h_{02}=333,94 \mathrm{~kJ} / \mathrm{kg}$. \\
\hline
\end{tabular}

Parameter untuk kondisi tiap titik dari siklus Otto udara standar dengan turbocharger dirangkumkan pada Tabel 4.

Tabel 4. Kondisi tiap titik siklus Otto udara standar dengan turbocharger

\begin{tabular}{|l|l|}
\hline \multicolumn{1}{|c|}{ Kondisi titik 1} & \multicolumn{1}{c|}{ Kondisi titik 2} \\
\hline$p_{1}=136,788 \mathrm{kPa}$ & $p_{2}=3424,90 \mathrm{kPa}$ \\
\hline$T_{1}=333,57 \mathrm{~K}$ & $T_{2}=835,193 \mathrm{~K}$ \\
\hline$V_{1}=0,00041527 \mathrm{~m}^{3}$ & $V_{2}=0,000041527 \mathrm{~m}^{3}$ \\
\hline \multicolumn{1}{|c|}{ Kondisi titik 3} & Kondisi titik 4 \\
\hline$p_{3}=22770,252 \mathrm{kPa}$ & $p_{4}=909,427 \mathrm{kPa}$ \\
\hline$T_{3}=5552,733 \mathrm{~K}$ & $T_{4}=2217,72 \mathrm{~K}$ \\
\hline$V_{3}=0,000041527 \mathrm{~m}^{3}$ & $V_{4}=0,00041527 \mathrm{~m}^{3}$ \\
\hline
\end{tabular}

Performansi Mesin Bensin

Perbandingan performansi mesin bensin tanpa dan dengan penggunaan Turbocharger diperlihatkan pada Tabel 5.

Tabel 5. Perbandingan performansi

\begin{tabular}{|c|c|c|}
\hline Parameter & Tanpa turbocharger & Dengan turbocharger \\
\hline mep & $2691,906 \mathrm{kPa}$ & $3238,314 \mathrm{kPa}$ \\
\hline$P_{i}$ pada $4400 \mathrm{rpm}$ & $147,5613 \mathrm{~kW}$ & $177,5136 \mathrm{~kW}$ \\
\hline$P_{s}$ pada $4400 \mathrm{rpm}$ & $65,09 \mathrm{~kW}$ & $65,09 \mathrm{~kW}$ \\
\hline$s f c$ pada $4400 \mathrm{rpm}$ & $292,675 \mathrm{gr} / \mathrm{kW} . \mathrm{jam}$ & $355,379 \mathrm{gr} / \mathrm{kW} . \mathrm{jam}$ \\
\hline$\eta_{m}$ & $44,11 \%$, & $36,66 \%$ \\
\hline$\eta_{v}$ & $98,46 \%$ & $98,45 \%$ \\
\hline
\end{tabular}

Dari perbandingan performansi pada Tabel 5 dapat dilihat bahwa daya indikator meningkat 16,87\% dengan penggunaan turbocharger, namun konsumsi bahan bakar spesifik, efisiensi mekanis, dan efisiensi volumetris mengalami penurunan dibanding tanpa turbocharger. 


\section{Daya dan Putaran Turbocharger}

Turbin digerakkan oleh gas buang dari mesin yang mengkopel langsung kompresor, sehingga daya yang diperlukan untuk memutar kompresor adalah daya yang dihasilkan turbin. Turbin dan kompresor dihubungkan dengan satu poros sehingga putaran dan daya turbin dengan kompresor adalah sama. Laju aliran udara melalui kompresor dihitung dengan Persamaan (7) pada putaran mesin 6000 rpm. Daya yang dihasilkan turbin sebesar 3,54915 kW dan daya ini berlaku untuk memutar kompresor. putaran turbin dan kompresor ditentukan dengan grafik karakteristik kompresor Gambar 7 pada putaran mesin 6000 rpm. Sehingga diperoleh putaran turbin dan kompresor turbocharger sebesar 59201,4966 rpm, dibulatkan menjadi 59200 rpm dengan efisiensi turbocharger pembacaan grafik sebesar $73 \%$.

\section{KESIMPULAN}

Berdasarkan hasil analisa termodinamika dan perhitungan performansi mesin 3SZ-VE DOHC VVT-i diperoleh kesimpulan berikut:

a) Hasil analisa termodinamika mesin bensin tanpa penggunaan turbocharger diperoleh nilai kalor yang disuplai ke dalam silinder mesin $Q_{\text {in }}$ sebesar $1,659 \mathrm{~kJ}$, kalor yang dibuang $Q_{\text {out }}$ sebesar 0,660 kJ, kerja bersih siklus yang dihasilkan $W_{\text {nett }}$ sebesar $1,0061 \mathrm{~kJ}$, dan efisiensi termal siklus sebesar 60,64\%. Sedangkan hasil analisa termodinamika mesin bensin dengan penggunaan turbocharger diperoleh nilai kalor yang disuplai ke dalam silinder mesin $Q_{\text {in }}$ sebesar 2,01526 kJ, kalor yang dibuang $Q_{\text {out }}$ sebesar 0,8084 kJ, kerja bersih siklus yang dihasilkan $W_{\text {nett }}$ sebesar 1,21032 kJ, dan efisiensi termal siklus sebesar 60,06\%. Dalam hal ini daya bersih $W_{\text {nett }}$ dengan penggunaan turbocharger meningkat sebanyak 20,29\% dibandingkan tanpa penggunaan turbocharger.

b) Hasil perhitungan performansi mesin bensin tanpa penggunaan turbocharger diperoleh tekanan efektif ratarata mep sebesar 2691,906 $k P a$, daya indikator $P_{i}$ pada putaran $4400 \mathrm{rpm}$ sebesar $147,5613 \mathrm{~kW}$, daya poros $P_{s}$ pada putaran $4400 \mathrm{rpm}$ sebesar 65,09 $\mathrm{kW}$, konsumsi bahan bakar spesifik $s f c$ pada putaran $4400 \mathrm{rpm}$ sebesar 292,675 $\mathrm{gram} / \mathrm{kW}$.jam, efisiensi mekanis $\eta_{m}$ sebesar 44,11\%, dan efisiensi volumetrik $\eta_{v}$ sebesar 98,46\%. Sedangkan hasil perhitungan performansi mesin bensin dengan penggunaan turbocharger diperoleh tekanan efektif rata-rata mep sebesar $3238,314 \mathrm{kPa}$, daya indikator $P_{i}$ pada putaran $4400 \mathrm{rpm}$ sebesar $177,5136 \mathrm{~kW}$, daya poros $P_{s}$ pada putaran $4400 \mathrm{rpm}$ sebesar 65,09 $\mathrm{kW}$, konsumsi bahan bakar spesifik $s f c$ pada putaran $4400 \mathrm{rpm}$ sebesar 355,379 $\mathrm{gram} / \mathrm{kW}$.jam, efisiensi mekanis $\eta_{m}$ sebesar 36,66\% dan efisiensi volumetrik $\eta_{v}$ sebesar $98,45 \%$.

c) Daya yang diperlukan untuk memutar kompresor adalah daya yang dihasilkan oleh turbin, sehingga diperoleh $W_{\text {Turbin }}$ sama dengan $W_{\text {Kompresor }}$ sebesar 3,54915 $\mathrm{kW}$ dengan laju aliran gas buang masuk turbin $\dot{m}_{\text {ex }}$ sebesar $0,03509 \mathrm{~kg} / \mathrm{s}$ dan laju aliran udara melalui kompresor $\dot{m}_{u, c}$ sebesar $0,10516 \mathrm{~kg} / \mathrm{s}$. Putaran turbocharger yang diperoleh menggunakan grafik karakteristik kompresor sentrifugal adalah 59200 rpm pada saat putaran mesin bensin 6000 rpm serta efisiensi turbocharger 73\%.

\section{DAFTAR PUSTAKA}

[1]. http://id.wikipedia.org/wiki/Turbocharger diakses Tanggal 11 Juni 2015.

[2]. http://www.balipost.co.id/mediadetail.php?module=detailberita\&kid=14\&id=31900 diakses Tanggal 11 Juni 2015.

[3]. Santoso, I., (2006). Perancangan Turbin Gas dan Blower pada Turbocharger untuk Motor Bensin 1500 cc. Universitas Muhammadiyah Malang.

[4]. Agustinus., (2011). Perancangan Kompresor Sentrifugal pada Turbocharger Motor Bensin 1500 cc untuk Menaikkan Daya Maksimal sebesar 25\%. Jurusan Teknik Mesin, ITS, Surabaya.

[5]. Maulana, F., (2009). Kajian Performansi Mesin Non Stationer (Mobile) Berteknologi VVT-i dan Non VVT-i. Departemen Teknik Mesin, USU, Medan.

[6]. Cengel, Y. A., \& Boles, M. A. (2006). Thermodynamics: An Engineering Approach. 4th ed. McGraw-Hill, New York.

[7]. Aghaali, H. (2012). On-Engine Turbocharger Performance Considering Heat Transfer. Licentiate Thesis, Department of Machine Design, Royal Institute of Technology.

[8]. Kusmawadi, A. (2008). Kajian studi pengaruh penggunaan turbocarjer dengan interkuler terhadap performansi mesin diesel 130 PS penggerak kendaraan truk. DTM, FT-USU, Medan.

[9]. Rajput, R. K., (2005). A Textbook of Internal Combustion Engine. First Edition. Laxmi Publication, New Delhi, India. 
[10]. Simon, V., Mayer, M. (2000). Exhaust Gas Temperature $1050^{\circ} \mathrm{C}$, An engineering challenge. BorgWarner Turbo Systems.

[11]. Heywood, J. B. (1988). Internal Combustion Engine Fundamentals. Mc-Graw Hill.

[12]. Dixon, S. L. (1998). Fluid Mechanics, Thermodynamics of Turbomachinery. Fourth Edition. Jordan Hill, Oxford.

[13]. Mitianiec, W., Rodak, L. (2011). Control Problems in a Turbocharged Spark-Ignition Engine. Journal of Kones Powertrain and Transport, vol. 18.

[14]. http://www.kadekticaret.com/turbobenefits.htm diakses tanggal 24 Agustus 2015. 